\title{
Pola Komunikasi Kelompok pada Komunitas Pecinta Film Islami
}

\author{
Aqoma Soleh \\ Jurusan Komunikasi dan Penyiaran Islam, Fakultas Dakwah dan Komunikasi, UIN Sunan \\ Gunung Djati, Bandung \\ Email:aqomainamorta@gmail.com
}

\begin{abstract}
The rapid development of films increases the birth of communities. Film lovers are one of the Islamic Film Lovers Community (KOPFI). In the Islami c Film Lovers Community a new social space is formed which influences the interaction and communication behavior between group members. The purpose of this study is to find out the process of communication and evaluation in finding the unity of opinion in the Bandung Islami c Film Lovers Community. The method used is a qualitative method with the Social Comparison Theory approach from Festinger. Data is collected through observation and interviews. The results of the study show that members of the Bandung Islami c Film Lovers Community in their activities have roles which are in accordance with the structure and level of their main tasks and functions. Communication patterns become an important tool that must be considered to maintain harmony and cohesiveness in the community of Bandung Regional Islami c Film Lovers. As a film discussion forum, Members of the Islami c Film Lovers Community evaluate and share information using various languages as group identities.
\end{abstract}

Keywords : Group Communication; Community of Islami c film lovers; Social Comparison Theory

\begin{abstract}
ABSTRAK
Perkembangan film yang semakin pesat mendorong lahirnya komunitas-komunitas pecinta film salah satunya Komunitas Pecinta Film Islami (KOPFI). Di KOPFI dalam komunikasi kelompoknya terbentuk ruang sosial baru yang memengaruhi perilaku interaksi dan komunikasi antar anggota kelompok. Penelitian ini bertujuan untuk mengetahui pola komunikasi, evaluasi diri, perbandingan dan perbaikan diri di Komunitas Pecinta Film Islami (KOPFI) Bandung. Metode penelitian yang digunakan adalah metode kualitatif dengan pendekatan Teori Perbandingan Sosial dari Festinger. Data dikumpulkan melalui observasi, wawancara dan dokumentasi. Hasil penelitian menunjukkan bahwa anggota Komunitas Pecinta Film Islami Bandung dalam kegiatannya memiliki peran yang sesuai dengan struktur dan tingkatan dari tugas pokok dan fungsinya. Pola komunikasi menjadi sebuah alat penting yang mampu menciptakan atau menjaga keharmonisan dan kohesivitas di komunitas Pecinta Film Islami Regional Bandung. Sebagai forum diskusi film, Anggota Komunitas Pecinta Film Islami saling melakukan evaluasi dan berbagi informasi, pengetahuan dan pengalaman yang dapat
\end{abstract}


menuingkatkan kemampuan masing-masing anggota, dengan menggunakan ragam bahasa sebagai identitas kelompok.

Kata Kunci : komunikasi kelompok; teori perbandingan sosial; komunitas pecinta film

\section{PENDAHULUAN}

Produksi film saat ini berkembang pesat di Indonesia, dan banyak dinikmati oleh berbagai kalangan, mulai dari anak-anak, remaja, dewasa sampai orang tua. Film yang beredar di pasaran tersebut memiliki beragam konten termasuk konten cenderung bermuatan negatif yang perlu diwaspadai. Untuk itu munculkan keinginan dari beberapa kelompok masyarakat untuk membedah dan mendiskusikan produk-produk film tersebut termasuk mensosialisasikan dan mencintai produk film yang memiliki konten positif, terutama berisi konten Islami dan memiliki nilai dakwah. Salah satu komunitas pecinta film yang cukup aktif tersebut adalah Komunitas Pecinta Film Islami (KOPFI).

Komunitas Pecinta Film Islami adalah sebuah komunitas yang terbentuk dalam rangka memberikan wadah atau tempat untuk rekan-rekan pecinta hal-hal yang berbau film Islami . bukan hanya sekadar untuk menikmati karya-karya film yang Islami tersebut tapi juga melihat seperti apa makna dan mengkritisi film tersebut dari sudut pandang seorang muslim. Kata 'Islami' yang dipilih, mengukuti makna dalam KBBI (2015) adalah 'akhlak' dalam Islam, dilakukan agar dapat menegaskan bahwa komunitas ini selalu memberikan dukungan kepada film baik yang memiliki akhlak atau yang tidak bertentangan dengan ajaran islam. Harapan dari komunitas ini adalah agar dapat menjadi wadah kumpul generasi penerus bangsa yang mana mampu memberikan semangat dan kritik kepada para sineas Indonesia dan Production House besar agar dapat melahirkan sebuah karya yang baik dan dapat membakar semangat kebaikan kepada para pemuda Indonesia.

Anggota KOPFI berisi para Pencinta film yang Islami dengan tegas menyatakan bahwa sebagai penikmat film, Kopfi bukan hanya menjadi penikmat karya-karya dari orang lain saja, tapi juga berusaha mencari dan menggali hikmah dan arti dari film tersebut, melalui sudut pandang seorang muslim. Sehingga hal ini menjadi upaya dari semua pengurus Kopfi agar dapat memberikan kontribusi terhadap manfaat dari komunitas ini untuk para sineas dan untuk para pecinta film, khususnya film yang bernafas Islami .

Kopfi Bandung sebagai sebuah regional dari KOPFI Indonesia juga memiliki kegiatan yang berhubungan dengan dunia perfilman, seperti diskusi dan bedah film, Nonton bareng film yang bertema Islami, dan lain sebagainya yang tentu saja merupakan kegiatan Positif. Suatu komunitas pasti memiliki keinginan untuk membedakan dirinya dengan komunitas lain. Komunitas sendiri diartikan 
Aqoma Soleh

sebagai sebuah kelompok sosial dari beberapa organisme yang berbagi lingkungan umumnya memiliki ketertarikan dan habitat yang sama. Komunitas juga merupakan sekumpulan individu yang di dalamnya memiliki maksud, kepercayaan, sumber daya, preferensi, kebutuhan, risiko, dan sejumlah kondisi lain yang serupa (Wenger, 2002). Melalui komunitas ini setiap individu dapat mencoba untuk mengetahui karakteristik tentang setiap individu.

Berdasarkan uraian tersebut, komunitas menjadi sebuah wadah dari berbagai macam karakter manusia yang berkumpul dalam sebuah kesamaan ketertarikan, dimana komunikasi antar individu, dan kelompok tidak dapat dihindari, sehingga penelitian ini berusaha menelaah lebih jauh mengenai seperti apa Komunikasi kelompok dalam suatu komunitas, yang mana dalam penelitian ini dipilih Komunitas Pecinta Film Islami Bandung, sebagai Objek penelitiannya.

Sejumlah penelitian tentang perilaku komunikasi kelompok sudah banyak dilakukan, diantaranya adalah penelitian yang dilakukan Joni Iskandar (2018) tentang pengaruh komunikasi interpersonal dan komunikasi kelompok terhadap kohesivitas kelompok pada supporter persebaya korwil suramadu. Iskandar mengungkapkan bahwa komunikasi interpersonal dan komunikasi kelompok merupakan hal yang penting dalam sebuah komunitas, termasuk komunitas supporter bola. komunikasi interpersonal dan komunikasi grup menurut Iskandar berpengaruh secara signifikan terhadap kekompakan kelompok di Persebaya Korwil Pendukung Suramadu.

Pengaruh komunikasi kelompok juga ditunjukkan pada level industri. Akarika, D.C.(2017), pola komunikasi menjamin keharmonisan sebuah lembaga pendidikan di Nigeria. Dan untuk mencapai komunikasi yang efektif baik vertikal maupun horizontal diperlukan pelatihan yang periodik. Manajemen harus mendorong para karyawan agar mampu berpartisipasi dalam mengambil keputusan. Penelitian ini menunjukkan sisi manfaat praksis dari komunikasi yang harus terbangun.

Penelitian lainnya dilakukan oleh Saufa Yardha (2017) tentang komunikasi kelompok dalam membentuk konsep diri pada komunitas seribu guru Aceh di Banda Aceh. Yardha mengungkapkan bahwa komunikasi yang terjadi dan terjalin antara sesama anggota dan volunteer berjalan dengan baik, komunikasi kelompok dalam komunitas dapat membentuk konsep diri anggotnya serta konsep diri juga mengarah kepada konsep diri positif yaitu meningkatkan rasa kepedulian, meningkatkan rasa percaya diri akan kemampuan diri yang dimiliki, memiliki banyak teman, menjadi lebih menghargai orang lain dan meningkatkan kemampuan berkomunkasi dengan baik. Menurut Yardha melalui komunitas Seribu Guru Aceh seluruh anggota mempunyai kemampuan, berbagi ilmu dan 
pengalaman, kepada anak-anak yang membutuhkan, terutama anak-anak yang berada di daerah pedalaman dalam mengecap pendidikan.

Penelitian di atas lebih condong kepada konsep diri dan bagaimana pengaruh dari komunikasi kelompok dalam sebuah komunitas. Penelitian ini lebih membahas segi kegiatan evaluasi dalam sebuah komunitas dan bagaimana interaksi sosial yang terjadi dalam komunikasi kelompok di komunitas pecinta film Islami Bandung dan menggambarkan seperti apa fenomena komunikasi kelompok yang terjadi dalam sebuah komunitas pecinta film, khususnya film Islami . Berdasarkan uraian tersebut maka dapat dikemukakan pertanyaan yang mendasari penelitian ini yakni: bagaimana pola komunikasi, evaluasi diri, perbandingan dan perbaikan diri yang terjadi di dalam komunikasi kelompok komunitas pecinta film Islami bandung? Tujuan penelitian ini adalah untuk memperoleh deskripsi lengkap tentang Pola komunikasi, proses evaluasi yang terjadi, Perbandingan dan Perbaikan diri pada anggota kelompok Komunitas Pecinta Film Islami Bandung. Kontribusi yang didapatkan dari penelitian ini adalah menambah pengembangan teoretis terhadap kajian komunikasi kelompok pada komunitas melalui Perbandingan Sosial. Pada sisi lain hasil penelitian dapat memberikan gambaran pola interaksi dan komunikasi pada komunitas dalam membentuk kohesivitas kelompok. Penelitian ini dilakukan di kota Bandung, dimana Bandung merupakan salah satu regional dari Komunitas Pecinta Film Islami yang sudah tersebar diberbagai kota di Indonesia.

Penelitian ini menggunakan metode penelitian deskriptif kualitatif dengan paradigma interpretif. Menurut F. L. Whitney, penelitian deskriptif digunakan agar dapat mencari data melewati interprestasi secara benar dan tepat Nazir, 2003: 54). Aspek selanjutnya yang difokuskan dalam perspektif interpretif adalah subjektivisme atau keunggulan pengalaman dari individu. Teori-teori interpretif memberikan gambaran mengenai proses pikiran yang aktif dalam mengingat kembali pengalaman individu atas kejadian apapun yang telah dialaminya (Littlejohn, 1999: 15).

\section{HASIL DAN PEMBAHASAN}

Teori yang digunakan dalam penelitian ini adalah teori Perbandingan Sosial. Menurut Teori ini dalam komunikasi kelompok memandang Individu di berbagai tempat selalu terkait dengan proses perbandingan sosial, seperti membuat penilaian mengenai orang lain dan dirinya sendiri, menerima bahwa mereka tidak memiliki kebebasan dalam bertindak, dan membentuk kesan mengenai orang lain. Berbagai perilaku sosial ini dituangkan oleh beberapa psikolog sosial dalam penelitian yang kemudian menghasilkan berbagai macam teori sosial. Salah satunya adalah teori perbandingan sosial. 
Komunikasi melakukan sejumlah hal atau fungsi dengan banyak cara untuk menentukan hasil kelompok. Ini adalah sarana untuk berbagi informasi, cara anggota kelompok menyelidiki dan mengidentifikasi kerusakan dalam pikiran, dan sebuah cara persuasi (Simon, 1976; 344).

Misalnya dalam sebuah kelompok terjadi ketidak kompakan dalam sebuah argumen, maka hal ini akan menimbulkan keretakan dalam sebuah keharmonisan dari kelompok tersebut, sehingga proses komunikasi dengan cara persuasive akan membantu dalam mencari apa saja hal yang menjadi penyebab keretakan dalam kelompok ini. Hal ini bias dilakukan melalui proses evaluasi di dalam kelompok tersebut, mencari tau perbedaan argumen seperti apa yang akhirnya mengundang keretakan dalam sebuah kelompok. Teori perbandingan adalah salah satu teori yang cocok dalam mengkaji fenomena tersebut.

Teori perbandingan sosial diformulasikan oleh Festinger (dalam Shaw \& Costanzo, 1982). Perkembangan teori ini dimulai dengan suatu pertimbangan mengenai komunikasi sosial tentang perubahan opini dalam kelompok sosial. Umumnya, teori ini melihat bahwa proses pengaruh sosial dan beberapa perilaku kompetitif tertentu berasal dari kebutuhan untuk mengevaluasi diri dan kepentingan untuk evaluasi ini berdasar pada perbandingan dengan orang lain. Prinsip utama dari teori proses perbandingan sosial diajukan oleh Festinger dalam bentuk hipotesis, kesimpulan dan derivasinya. Pernyataan tersebut berhubungan dengan kebutuhan untuk evaluasi, sumber evaluasi, pilihan seseorang dalam melakukan perbandingan, faktor-faktor yang mempengaruhi perubahan, berkurangnya perbandingan dan tekanan untuk mencapai kesatuan.

Kelompok adalah sekumpulan orang yang memunyai tujuan bersama dan yang berinteraksi satu sama lain untuk mencapai tujuan bersama, mengenal satu sama lainnya, dan memandang mereka sebagai bagian dari kelompok tersebut (Mulyana, 2008). Menurut Johnson dan Johnson dalam Derry (2005), komunikasi kelompok dapat lebih bisa dipahami sebagai suatu pola interaksi daripada sebagai suatu rangkaian keterampilan khusus. Sebuah kelompok yang melakukan komunikasi akan menimbulkan perilaku komunikasi.

Komunitas pecinta film Islami juga melakukan hal yang berkaitan dengan hal diatas, yaitu mencari informasi yang terkait dengan sebuah film yang mempunyai kandungan Islami . Dari film tersebut maka didapatkan beberapa opini mengenai film tersebut yang mungkin, setiap individu memiliki opini yang berbeda, sehingga proses diskusi sangat penting dalam hal ini untuk memperoleh tujuan tertentu.

Dalam sebuah komunitas terdapat peran dari orang sekitar atau orang lain yang dapat mempengaruhi pola pikir anggota komunitas tersebut, dan mungkin saja orang tersebut berada di dalam kelompok dimana kita juga menjadi 
anggotanya, formal atau informal, Besar atau kecil. Kelompok orang tersebut dapat memiliki dampak yang cukup besar terhadap cara kita menerima pesan.

Keanggotaan kelompok dapat menciptakan sikap prasangka yang sulit diubah. Berikut adalah Beberapa jenis-jenis dari sebuah kelompok penting. Kelompok Primer (primary group) adalah sebuah kelompok (dua orang atau lebih) yang melibatkan perkumpulan yang anggotanya bertemu langsung dengan akrab selama jangka waktu yang lama. Kelompok Acuan (refference group) adalah sebuah kelompok yang dikenali dan digunakan sebagai standar acuan namun tidak mesti dimiliki. Kelompok Kasual (casual group) adalah sekelompok orang yang terbentuk satu kali saja dan anggota kelompok tersebut tidak saling mengenali satu sama lainya sebelum mereka berkumpul (Severin, 1990: 219-220).

Dalam komunitas Pecinta film Islami terdapat media yang biasanya mereka gunakan untuk berkomunikasi antara anggota satu dengan yang lain baik itu dalam satu komunitas di satu kota maupun komunitas pecinta film Islami yang berbeda kota. Anggota KOPFI biasanya menggunakan media informasi berupa news letter/artikel tentang Film, Dvd, majalah Film dan tentu saja Internet atau Sosial Media. Pertukaran informasi yang terjadi tersebut biasanya menjadi sarana sosialisasi dan Perkembangan kegiatan bagi anggota komunitas yang baru bergabung atau ingin mengetahui lebih dalam mengenai Komunitas Pecinta Film Islami khususnya di Regional Bandung.

Perbandingan sosial sebagai penilaian komparatif mengenai stikulus sosial pada dimensi tertentu. Festinger mengajukan teori proses perbandingan sosial untuk menjelaskan perbandingan komparatif yang berhubungan dengan opini dan kemampuan seseorang. Festinger menyatakan bahwa individu termotivasi untuk membandingkan diri mereka sendiri dengan orang lain yang spesifik atau umum untuk menilai situasi sosial mereka sendiri. Individu cenderung untuk membandingkan diri mereka dengan individu lain yang serupa dengan dirinya sendiri, sebab dengan melakukan hal tersebut, maka evaluasi yang lebih tepat mengenai opini maupun kemampuan yang dimilikinya dapat tersedia (Kaplan dan Stiles, 2004).

Teori ini mempunyai keterkaitan antara dorongan terhadap sebuah evaluasi perilaku yang dilakukan oleh seseorang di dalam sebuah kelompok, sehingga hal ini berkaitan dengan strukutur dari kelompok tersebut dan dinamika kelompok tersebut. Alasan yang pertama adalah, karena perbandingan dapat dilakukan didalam sebuah kelompok, seseorang anggota dalam sebuah kelompok dapat melakukan evaluasi diri dan melakukan asosiasi dengan anggota kelompok lainnya. Kedua, kelompok yang memberi suatu kepuasan adalah kelompok yang mempunyai opini yang hampir dekat dengan opini yang dimiliki oleh anggotanya, atau orang yang bersangkutan dengan kelompok tersebut. Oleh 
Aqoma Soleh

karena itu orang yang lebih tertarik ke kelompok yang memiliki opini yang sama dan cenderung menjauh apabila kelompok yang dia ikuti mempunyai opini atau pendapat yang berbeda

Demikian penting kedudukan teori khususnya dalam suatu kegiatan penelitian, sehingga hampir tidak ada sesuatu yang tidak berangkat dari teori dengan satu atau beberapa fungsinya. Kemudian sebuah teori diarahkan untuk menjawab pertanyaan mengapa (bagaimana) timbul regularitas alam, dengan demikian teori harus memuat pertanyaan tentang mekanisme tertentu, serta hubungan antar variabel dalam fenomena yang diselidiki (Kaplan dan Manners, 2002: 123).

Komunikasi merupakan proses dimana suatu ide dialihkan dari sumber kepada satu penerima atau lebih dengan maksud mengubah perilaku. Dalam komunikasi ada sebuah proses pengoperan (pemrosesan) ide, gagasan, lambang, dan di dalam proses itu melibatkan orang lain. Harold D Lasswell menyatakan bahwa cara yang baik untuk menggambarkan komunikasi adalah dengan menjawab siapa menyatakan apa dengan saluran apa kepada siapa dan efeknya bagaimana. (Fajar, 2009: 32).

Berkaitan dengan hal tersebut, Komunikasi juga merupakan hal penting dalam sebuah kelompok menyampaikan sebuah opini. kadang, individu dalam kelompok tersebut menyampaikan opininya, menggunakan teknik komunikasi yang kurang tepat sehingga penyampaian ide, gagasan dan opini justru menjadi sumber konflik dan menhadi penyebab keretakan dalam sebuah keharmonisan kelompok.

Hafied Changara (2000) menyatakan bahwa, proses komunikasi dapat terjadi dikarenakan adanya orang yang melakukan intepretasi terhadap sebuah objek dan pemikirannya. Objek itu dapat berupa benda, alam, informasi, pengalaman, peristiwa, atau fakta yang di jadikan sesuatu yang berarti untuk manusia. Beberapa objek itu dapat terjadi di dalam diri sendiri dan diluar dari diri orang tersebut. Selanjutnya objek tersebut dapat diberi arti, diinterpretasikan berdasarkan dari pengalaman yang mempengaruhi sikap dan perilaku seseorang. Oleh karena itu setiap individu masing-masing berbeda dalam memberikan interpretasi dan kepekaan diri, sehingga setiap orang berbeda pula ketika memproses hasil penentuan dari tindakan apa yang akan telah dilakukan.

Perubahan opini, sikap dan perilaku membuat komunikasi dalam kelompok menjadi sebuah hal yang sangat penting. individu yang bergabung dalam sebuah kelompok, misalnya komunitas pecinta film Islami , pasti memiliki perbedaan opini, sehingga bagaimana individu lain harus bisa mengubah opini yang berbeda tersebut, agar memperolah kesamaan dalam pandangan di kelompoknya. 
Dalam kegiatan berkomunikasi, khususnya komunikasi yang efektif, maka efek atau perubahan diharapkan terjadi bukan saja pada seseorang, melainkan kepada orang banyak atau masyarakat. Khalayak penerima yang terdiri dari banyak orang menjadi sasaran pesan komunikasi yang diharapkan efektivitasnya.

Masing-masing individu memiliki perbedaan dalam mempraktekkan komunikasi. dai hal tersebut, maka dalam komunikasi dikenal dengan pola-pola tertentu sebagai manifestasi perilaku manusia dalam berkomunikasi. Pola komunikasi dibagi menjadi empat, yakni komunikasi antarpribadi, komunikasi kelompok kecil, komunikasi publik dan komunikasi massa.

Komunikasi kelompok memiliki tujuan dan organisasi (meskipun tidak selalu formal) dan melibatkan interaksi diantara anggota-anggotanya. Jadi, ada dua tanda kelompok secara psikologis yaitu : (a) Anggota-anggota kelompok merasa terikat dengan kelompok (ada sense of belonging, yang tidak dimiliki orang yang bukan anggota). (b) Nasib anggota-anggota saling bergantung, sehingga hasil setiap orang terkait dalam cara tertentu dengan hasil yang lain.

Ada empat faktor situasional yang mempengaruhi efektifitas komunikasi kelompok adalah, ukuran kelompok, jaringan komunikasi, kohesi kelompok, kepemimpinan. Seperti halnya tindakan komunikasi, peranan yang dimainkan oleh anggota kelompok dapat membantu penyelesaian tugas kelompok, memelihara hubungan emosional yang baik, atau hanya mementingkan kepentingan individu saja (Riswandi, 2008: 120-128).

Komunikasi merupakan sebuah instrumen utama dalam kehidupan sosial bermasyarakat. Saat ini komunikasi tidak hanya membahas satu orang ke orang lainnya tetapi juga menyangkut khalayak yang banyak dan di berbagai tempat dan daerah yang berbeda, kemudian disebut sebagai komunikasi massa. Sebuah kelompok dewasa ini tidak hanya melakukan komunikasi secara langsung dalam bertukar informasi, tetapi bias juga melakukan komunikasi secara online, seperti menggunakan social media. Dengan social media, proses komunikasi akan lebih mudah.

\section{Sejarah KOPFI}

KOPFI atau Komunitas Pencinta Film Islami didirikan pada tanggal 7 Oktober 2015 di kota Yogyakarta. KOPFI dibentuk oleh sekelompok anak muda yang menyukai hal-hal yang berbau film yang ada di indonesia, terutama film baik dan Islami . Kata 'Islami ' yang dipilih, dimana menurut KBBI adalah 'akhlak' islam, dilakukan untuk menegaskan bahwa komunitas ini adalah komunitas yang hanya mendukung film baik yang memiliki akhlak (yang tidak bertentangan dengan ajaran islam). Komunitas ini di harapkan dapat menjadi sebuah wadah untuk berkumpulnya para generasi penerus dari bangsa ini yang mampu memberikan 
Aqoma Soleh

kontribusi terhadap para sineas Indonesia dan Production House raksasa untuk melahirkan karya baik yang menjadi akhirnya dapat menjadi pembakar semangat kebaikan untuk para pemuda Indonesia.

KOPFI sebagai sebuah wadah Pencinta film yang Islami kembali memberikan penegasan bahwa sebagai seorang penikmat dan pecinta film Islami , KOPFI tidak hanya sekadar menikmati dari karya-karya sineas dan karya-karya film yang Islami nya saja, tapi KOPFI juga berupaya untuk menggali dan mencari sebuah makna, serta mencoba mengkritisinya dari sudut pandang seorang Muslim, terutama Anak muda Muslim. Pandangan tersebut dapat pula berangkat dari kursi para penonton dan juga dari kursi orang-orang yang setelah menonton sebuag film dan paham film secara komprehensif. Sehingga kritik dan saran yang diberikan dan disampaikan dapat menjadi sesuatu yang memberikan sebuah hal yang berarti berharga bagi para sineas film baik dan Islami .

KOPFI mengawali sebuah langkah yang cukup signifikan dari Kota Pelajar, Yogyakarta. Dalam waktu yang tidak begitu lama, setelah jogja KOPFI dari Pekanbaru dan KOPFI Samarinda pun terbentuk. Setelah 3 bulan berdiri dan berjalan KOPFI berhasil melebarkan sayap dan jala kebaikan ke beberapa kota, bahkan sampai ke 34 kota di Indonesia dan 3 negara (Malaysia, Australia dan Korea Selatan) dengan memanfaatkan jaringan-jaringan yang ada pada para pemuda di Indonesia yang sedang beradsa di kota-kota tersebut dan yang sedang menimba ilmu di sana.

Dalam perjalanannya sebagai sebuah Komunitas Pecinta Film, KOPFI memiliki beberapa tujuan yang menjadi landasan dalam komunitas ini. KOPFI berusaha menjadi sarana yang professional dalam menghubungkan antara masyarakat secara luas dengan kepentingan para sineas dari perfilman Indonesia yang telah berkarya dengan memproduksi film baik dan Islami . Promotor dan distributor di Indonesia sering kali memberikan trend yang kurang baik dalam mendistribusikan filmnya, sehingga KOPFI berusaha untuk menjadi Promotor atau distributor yang dapat menciptakan sebuah trend yang positif di kalangan anak muda (khususnya) melalui ajakan untuk menonton film baikdan Islami . KOPFI juga dapat menjadi sarana dakwah atau media dakwah yang menggandeng media lain, komunitas lain, bahkan sponsorship agar dapat ikut serta mendukung kegiatan yang positif ini.

Dilihat dari tujuan tersebut dapat disimpulkan bahwa KOPFI memiliki sebuah integritas dalam menyusun tujuan dari sebuah komunitas. Dengan hal ini KOPFI berharap dapat memberikan kontribusi yang positif dalam dunia perfilman di Indonesia dan dapat pula menjadi tolak ukur dalam menciptakan sebuah karya yang positif bagi para penontonnya dengan menjadi trend yang positif terutama untuk kalangan anak muda. KOPFI juga bisa menjadi sarana 
Dakwah, terutama dakwah yang ada di media massa, dengan bekerjasama dengan beberapa media yang ada di Indonesia atau dengan bekerja sama dengan beberapa sponsorship yang dapat mendukung kegiatan yang positif, seperti kegiatan nonton bareng film yang bertemakan Islami .

KOPFI juga memiliki sebuah tujuan penting lainnya yaitu menjadi sebuah komunitas yang mandiri dan dapat meraih profit yang nantinya akan terus melestarikan karya karya dari anak bangsa yaitu berupa film terutama film yang bertemakan Islami . Sehingga Film Indonesia (yang baik dan Islami) dapat lebih dihargai di tanahnya sendiri.

Selain tujuan, KOPFI juga memiliki sebuah Visi yakni "Terciptanya lingkungan yang kondusif bagi masyarakat Indonesia melalu tayangan film layar lebar yang Islami dan film baik bernafaskan islam yang menginspirasi."

Misi dari kopfi tentu saja membentuk sebuah mental dan pemikiran yang baik kepada generasi muda dan calon penerus bangsa agar memiliki sebuah sikap selalu menghargai, dan memberikan kritik kepada karya perfilman Indonesia dengan Bahasa yang baik, santun dan membangun. Selain itu juga membentuk sebuah jaringan di seluruh titik yang ada di Indonesia dan bahkan negara di seluruh dunia. Dari hal ini maka akan timbul dukungan yang besar terhadap para sineas di Indonesia, terutama yang memproduksi film baik dan Islami, sehingga memunculkan sikap bangga dari umat muslim di Indonesia khususnya.

KOPFI sendiri memiliki beberapa kriteria dalam menggandeng atau mengajak kerjasama sebuah karya film, yang pastinya harus sesuai dengan tujuan, visi dan misi dari KOPFI itu sendiri. Yang pertama adalah isi atau kontem yang di sampaikan oleh film tersebut tidak bertentangan dengan nilai dan ajaran yang ada di agama islam. Selain itu, film yang dutayangkan juga tidak boleh berisi konten yang mengandung unsur atau kegiatan yang bersifat Pornografi dan Pornoaksi. Film tersebut juga merupakan film yang baik dan menginspirasi untuk banyak orang dan tidak menjadi kontroversi di dalam sebuah masyarakat. KOPFI juga menyatakan bahwa film yang didukung oleh komunitas ini tidsk harus film yang bermuatan islam sebagai tujuan filmnya atau biasa disebut film religi, tapi KOPFI juga mendukung film baik, yaitu film yang bernafaskan islam, karena menurut KOPFI Agama islam adalah agama yang penuh dengan kebaikan, baik yang tersurat maupun yang tersirat.

KOPFI memilii banyak anggota diberbagai kota di Indonesia, namun Subjek yang diteliti pada penelitian kali ini lebih terfokus pada Komunitas pecinta film Islami yang berada di regional kota Bandung. KOPFI bandung saat ini telah memiliki hampir 80 orang anggota yang terdaftar, dan sering melakukan kegiatan rutin setiap minggunya, seperti hanya sekedar berkupul, atau diskusi 
Aqoma Soleh

mengenai film Islami yang sedang tayang atau pernah tayang di bioskop Indonesia.

\section{Pola Komunikasi dan di Komunitas Pecinta Film Islami Bandung}

Dalam kehidupan sosial bermasyarakat terutama dalam sebuah komunitas, ada individu-individu tertentu yang dengan mudah dapat menciptakan hubungan pertemanan ketika bertemu dengan teman yang baru. Selain itu pertemanan mereka pun biasanya dapat bertahan dalam waktu yang cukup lama. Sebaliknya, terdapat pula orang-orang yang mungkin mengalami kesulitan dalam pergaulan. Ada banyak faktor yang menjadi alasan dalam keberhasilan dan kegagalan seseorang anggota komunitas dalam pergaulannya, salah satunya adalah pola komunikasi mereka.

Pola komunikasi dapat bermacam-macam sesuai dengan karakter dari masing-masing anggota dalam sebuah komunitas. Misalnya dalam sebuah komunitas A memiliki anggota dengan pola komunikasi yang kaku, dan terlalu Birokratif, maka pola komunikasi yang dilakukan oleh para anggotanya pun terkesan bersifat kaku. Sebaliknya apabila pola komunikasi yang dilakukan dalam sebuah komunitas bersifat lentur dan fleksibel, maka pola komunikasi anggotanya pun mengikuti yaitu bersifat lentur dan fleksibel.

Tanpa disadari, sebenarnya pola komunikasi itu sendiri adalah berbagai kecenderungan dalam penyampaian isi pesan yang dikomunikasikan. Umumnya, seorang anggota komunitas dalam pergaulan bukan saja mengerti dampak dari pola komunikasinya terhadap orang lain, dia juga telah berhasil mengubahnya menjadi pola komunikasi yang santai dan menyenangkan. Pola komunikasi tidak hanya mempengaruhi isi pesan yang akan disampaikan, bahkan dengan gaya penyampaian yang santai akan menambah kekuatan bahkan melengkapi kekurangan isi pesan yang disampaikan.

Sebuah komunitas pada umumnya memakai dan mempunyai sebuah pola komunikasi yang dimana dalam menjalankan sebuah kegiatan dari komunitas tersebut atau dalam mencapai tujuan dari komunitas tersebut, secara khas memiliki pola komunikasinya sendiri. Misalnya dalam kasus KOPFI, dimana dalam mencapai tujuan dari komunitasnya, lebih banyak menggunakan pola komunikasi berbagai arah, fleksibel, dan lentur, untuk mencapai tujuannya, yaitu menciptakan masayarakat khususnya anak muda menjadi masyarakat yang mencintai sebuah karya yang bernafaskan Islami, sehingga muncul kesadaran akan hal tersebut. Kegiatan yang dilakukan dalam sebuah komunitas dapat dilakukan dengan lancar apabila terjadi sebuah komunikasi atau hubungan yang baik dan bagus antara pengurus inti dan anggota, maupun antara ketua dan bawahannya. KOPFI sebagai sebuah komunitas yang mana meiliki banyak anggota disetiap region nya, salah satunya di bandung yang memiliki hamper 80 
orang anggota, pastinya harus memperhatikan seperti apa pola komunikasi yang dilakuakn agar terciptanya keeratan hubungan antar sesama anggota.

Bentuk komunikasi yang terjadi di dalam komunitas Pecinta Film Islami di Kota Bandung bermacam-macam. Seperti komunikasi yang disebut, Nobar atau Nonton Bareng. Nonton bareng kadang dilakukan di bioskop di Bandung, atau bias juga dengan mengunjungi salah satu kampus atau tempat lain yang bias digunakan untuk Menonton sebuah film dengan layar besar, seperti di Taman Film, atau lokasi lainnya.

Selain nobar, kegiatan yang lain, yang sering mereka lakukan adalah kegiatan Gatering antar sesame anggota, atau sekedar kumpul di suatu tempat, misalnya di café atau di balai kota. Hal ini mereka lakukan karena penayangan sebuah film, terutama film yang bernafaskan religi, jadwalnya tidak menentu, kadang seminggu sekali, kadang sebulan sekali, sehingga untuk mengisi kekosongan tersebut, mereka melakukan pertemuan, untuk hanya sekedar silaturahmi dan saling bercerita.

Nobar dan kumpul atau gatering merupakan salah satu kegiatan yang sangat penting dalam bersilaturahmi antar sesama anggota. Dari sini dapat terlihat bagaimana pola komunikasi yang akan dilakukan oleh KOPFI. Ketika nobar, tidak akan terlihat bagaimana pola komunikasi yang terjadi, karena fokus para anggota terletak pada film yang mereka tonton. Pola komunikasi dapat terlihat ketika para anggota dari KOPFI sudah selesai melakukan nobar atau sebelum, karena dari situ dapat terlihat mereka saling berkomunikasi satu dengan yang lain, misalnya ketika sebelum melakukan Nobar, mereka berbicara satu dengan yang lain, ada yang berkelompok, namun ada yang berdua saja, bahkan ada yang sendiri, seperti tidak ada teman untuk diajak mengobrol atau sedang sibuk dengan aktifitasnya sendiri.

Dari sini terlihat bahwa pola komunikasi yang dilakukan oleh KOPFI bersifat fleksibel, sebelum kegiatan mereka dapat saling menyapa atau berkomunikasi sesuai dengan kemauan dan karakter mereka masing-masing. Namun dari hal ini biasanya timbul masalah selanjutnya, yaitu beberapa dari anggota akan merasa kurang nyaman, karena di acuhkan atau dibiarkan sendiri, ketika sebelum dan sesudah nobar. Dalam kegiatan ghatering atau kumpul bareng juga terlihat hal yang sama, ada satu atau dua orang yang terlihat sendiri, seperti tidak ada teman untuk diajak berbincang, sehingga mereka merasa terasingkan oleh anggota yang lainnya. Mereka yang merasakan hal ini biasanya adalah anggota baru yang masih belum bisa dapat berinteraksi dengan luwes atau masih malu-malu dan takut untuk bergabung dengan obrolan dari para seniornya, hingga akhirnya memilih untuk diam. Hal- hal seperti inilah dibutuhan sebuah evaluasi diri, untuk dapat bertahan dari sebuah komunitas atau kelompok 
Aqoma Soleh

di suatu masyarakat.

\section{Evaluasi Diri dalam KOPFI Bandung}

Dalam kelompok, asumsi awal seorang anggota kadang menimbulkan spekulasi yang salah terhadap orang lain, misalnya dilihat dari penampilannya, atau kemampuannya dalam kelompok tersebut. Hal ini pun terjadi dalam komunitas Pecinta Film Islami di Bandung, Anggota baru terkadang memiliki asumsi awal terhadap anggota yang sudah lama ataupun anggota baru lainnya. Asumsi tersebut bermacam-macam, dan menimbulkan opini yang memungkinkan terjadinya keraguan untuk melanjutkan keikutsertaan anggota ini dalam mengikuti kegiatan di KOPFI ini. Kegiatan Nobar, menjadi kegiatan yang dapat merubah opini orang tersebut, yang awalnya merasa tidak memiliki kemampuan dalam ikut melebur dalam komunitas ini, menjadi ikut masuk kedalam arus di komunitas ini.

Kegiatan nobar juga diikuti dengan kegiatan selanjutnya, yaitu me-review Film tersebut dengan kajian Islami . Islam dan kajian adalah satu kesatuan yang tidak dapat dipisahkan. Film isami juga merupakan objek yang dapat dikaji dalam sebuah kegiatan dakwah, misalnya melihat seperti apa konten Islami yang terkandung dalam sebuah film. Maka ha ini menjadi sarana dalam berdakwah social budaya, untuk membentuk mental yang baik dan menginspirasi bagi setiap anggota ataupun orang diluar anggota yang mengikuti acara Nobar ini.

Nobar merupakan kegiatan di Komunitas Pecinta Film Islami di bandung yang dapat melibatkan orang lain diluar anggota dari KOPFI itu sendiri, karena tujuannya adlah untuk mengkaji sebuah film bersama-sama dengan orang lain yang ikut menyaksikan di kegiatan nobar tersebut. Biasanya orang lain yang mengikuti kegiatan ini adalah orang yang sering berada dilingkungan tempat KOPFI Bandung berkunjung, atau orang yang memang menjadi bagian dari tempat tersebut. 


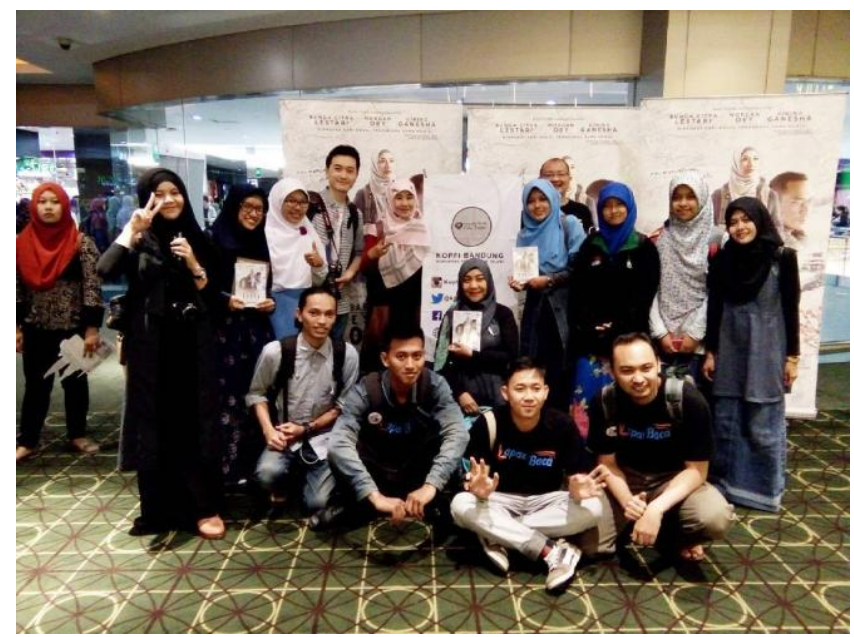

Sumber: Instagram Kopfi.id

\section{Gambar 1. Nobar Premier Hijab Traveler Love Spark in Korea}

Sebelum dan sesudah melakukan kegiatan Nobar maka biasanya diadakan Rapat dari pihak Kopfi sebagai penyelenggara Nobar. Hal ini dilakukan sebagai bentuk Evaluasi, mencari kekurangan atau kesalahan sebelum dan sesudah penyelenggaraan acara Nobar tersebut. Kegistan evaluasi ini untuk mengukur sejauh mana kekompakan dari setiap anggota, apakah sudah memiliki rasa memiliki dalam komunitas ini, dan apakah sudah memiliki opini dan tujuan yang sama dalam menjalani kehidupan social di komunitas ini.

Kemampuan diri dan opini menjadi variabel penting dalam Perbandingan sosial. Kadang seseorang cenderung melihat ke dirinya, apakah kemampuannya, baik dalam intelektual maupun dalam bergaul sudah sesuai dengan kelompok yang saat ini sedang dimasukinya. Dari hal ini maka akan timbul opini, yang akhirnya membentuk evaluasi diri terhadap kelompok yang saat ini dia ikuti. Bisa jadi hal ini membuat dia semakin yakin dan percaya dengan komunitas ini, dan akhirnya membentuk rasa sense of Belonging, atau justru sebaliknya, malah membuat orang tersebut menjadi tidak tertarik lagi dengan komunitas tersebut dan memutuskan untuk keluar dari komunitas tersebut.

Evaluasi diri dapat timbul dari diri sendiri melalui renungan atau pemikiran yang dalam terhadap masalah yang terjadi. Hal ini bisa terjadi karena pengalaman dalam hidup yang mana memberikan pelajaran terhadap bagaimana cara beradaptasi di suatu kelompok, yang mungkin pernah terjadi di pengalaman sebelumnya. Tapi hal ini bisa juga tidak dapat terjadi karena belum terbukanya pemikiran dan pengalaman dari diri sendiri, sehingga butuh bantuan dari orang lain, agar evaluasi diri dapat terjadi. Misalnya evaluasi yang dilakukan ketika 
Aqoma Soleh

berbincang dengan orang lain secara intim, berdua dan menceritakan keluh kesah dan masalah yang terjadi, dan mungkin orang ini dapat memberikan solusi, atau mengevaluasi hal apa yang harus dilakukan. Selain secara intim, evaluasi dengan orang lain dapat dilakukan didalam sebuah forum, yaitu evaluasi untuk mencari sebuah solusi bersama-sama. Menurut Silberstang, J. (2009), Pola komunikasi dapat berpengaruh terhadap adaptasi, transformasi, dan sumber daya profesional akan mampu memperbaiki sebuah pola komunikasi.

Evaluasi juga dapat dilakukan dengan membentuk sebuah forum diskusi, atau rapat dalam sebuah komunitas. Evaluasi tersebut bertujuan untuk membahas hal penting yang berhubungan dengan kelangsungan dari sebuah komunitas, seperti membahas kekurangan acara yang diselenggarakan, membahas anggota, berbagi cerita atau opini dalam sebuah komunitas sehingga menimbulkan keakraban dalam komunitas tersebut.

Kegiatan-kegiatan seperti itulah yang memperkuat solidaritas dan menjadi media komunikasi bagi anggota komunitas Pecinta Film Islami yang berada di Bandung. Namun, seiring dengan perkembangan jenis media serta kemajuan di bidang teknologi, anakanak dalam komunitas tersebut saling berinteraksi dan berkomunikasi dengan anggota komunitas Pecinta Film Islami di kota lainnya melalui internet.

\section{Perbandingan diri dan Perbaikan Diri Dalam KOPFI Bandung}

Setelah melakukan evaluasi diri, baik secara pribadi maupun evaluasi diri dalam sebuah forum, maka hal yang selanjutnya perlu dilakukan adalah membandingkan diri dengan anggota lain. Dari evaluasi maka akan ditemukan kesalahan atau kekurangan diri yang nantinya akan dicari pembanding dengan anggota lainnya. Misalnya dalam sebuah kelompok, ada anggota yang kurang inisiatif berbicara atau gabung duluan dalam sebuah perbincangan, maka untuk seterusnya, anggota tersebut akan kesulitan mendapatkan teman berbincang karena sifatnya yang kurang inisiatif membuka obrolan. Anggota tersebut akan secara otomatis membandingkan dengan anggota lainnya, bagaimana inisiatif anggota lain dalam membuka sebuah obrolan. Dari sini, akan timbul proses selanjutnya yang harus dilakukan, yaitu Perbaikan diri.

Perbaikan diri dilakukan setelah menemukan pembanding dengan anggota lainnya, dan secara sadar, melakukan hal yang sama dengan pembanding tersebut untuk memperbaiki kekurangan dalam sebuah kelompok. Dalam kasus diatas, anggota yang tadinya kurang inisiatif dalam membuka obrolan, akan secara sadar melakukan hal yang sama seperti yang dilakukan oleh orang lain yang menurutnya cepat diterima dalam sebuah pergaulan, yaitu lebih inisiatif daam membuka sebuah obrolan, agar kekurangan yang dirasakan dapat terselesaikan dan tidak timbul masalah yang dapat mengganggu keeratan dalam sebuah 
hubungan antar anggota di suatu komunitas.

Penelitian komunitas Pecinta Film Islami di Bandung ini, hubungan yang terjalin diantara mereka terjadi karena mereka memiliki kesamaan idealisme dan minat, yaitu Film yang memililiki konten yang Islami . Namun tidak hanya film yang Islami saja yang dapat membuat mereka bersatu, adanya komunikasi yang efektif dan pemikiran yang sama di dalam tujuan komunitas juga merupakan hal yang dapat mempererat hubungan di antara anggota-anggota komunitas Pecinta Film Islami di Bandung.

Kadang perbedaan opini sering terjadi diantara anggota pecinta film Islami ini, namun dengan adanya diskusi, evaluasi dan tentu saja kumpul-kumpul yang menyenangkan, membuat hal tersebut menjadi hilang. Di setiap komunitas pasti ada saja anggota yang saling membandingkan dengan anggota lainnya, misalnya dalm kasus di komunitas Pecinta Film Islami di bandung adalah anggota yang merasa dikucilkan, tidak seperti anggota lainnya yang dianggap ada, padahal hal tersebut merupakan asumsi awal yang timbul karena kemampuan dari anggota tersebut dalam bergaul, tidak seperti anggota yang lainnya, yaitu anggota yang merasa seperti itu biasanya anggota yang introvert dalam pergaulannya. Setelah itu anggota ini akan jarang mengikuti kegiatan yang dilaksanakan oleh KOPFI, sehingga apabila hal tersebut terjadi, maka ada salah satu pihak yang akan menanyakan kepada anggota tersebut, dan lebih merangkul anggotanya yang seperti itu, agar tidak menimbulkan masalah dalam diri anggota tersebut.

Pola komunikasi setiap individu anggota KOPFI berbeda satu dengan yang lain. Selain contoh kasus diatas, ada pula individu yang memiliki pola komunikasi yang fleksibel dan bisa menyesuaikan dengan kondisi dari individu lain di sekitarnya, sehingga dapat memberikan suasana yang menyenangkan dan mampu membuat lawan bicaranya nyaman berlama-lama berkomunikasi dengannya. Namun, ada pula anggota yang memiliki pola komunikasi yang pasif, atau dengan kata lain dapat mempersulit komunikasi yang sedang berlangsung. Padahal anggota ini merupakan anggota yang lama di dalam komunitas tersebut.

Pola komunikasi yang kurang baik tersebut antara lain berbicara hanya seadanya saja atau sepenggal-sepenggal dan kurang peduli terhadap masalah yang ada di sekelilingnya. Terbatasnya koordinasi antara kinerja otak dan indera pengucapan, membuat individu ini mengalami kekurangan dalam berkomunikasi secara efektif. Hal ini bahkan sering tidak disadari oleh individu tersebut. Sepanjang pengetahuannya, ia sudah mengatakan semua yang ingin disampaikanya padahal belum semuanya tersampaikan.

Selanjutnya ada anggota yang mempunyai pola komunikasi tipe pencair suasana yaitu orang yang mempunyai satu tujuan dalam hidupnya, yaitu 
membuat senang semua orang. Berbicara dengan tipe ini memang dapat membuat betah dan nyaman, karena respon yang diterima selalu berdampak pada kecenderungan positif, sehingga pola komunikasi seperti ini dapat mempererat hubungan antar pribadi. Sangat Susah untuk mencari tahu isi hati dari individu tipe seperti ini karena biasanya tipe seperti ini tidak terbuka, ketidakterbukaannya itu justru cenderung membuat orang ini menumpuk semua masalah dalam hati dan benaknya. Apabila tidak tertahankan, maka orang tipe ini dengan mudah menjadi orang yang depresi, tertekan, stress dan tidak bahagia, biasanya akan cenderung tiba-tiba berubah menjadi pendiam.

Uraian diatas menjelaskan bahwa pola komunikasi dapat melambangkan kepribadian seseorang anggota di komunitas yang sesungguhnya, tapi terdapat kemungkinan hal tersebut merupakan pola yang sedang dibahas dan dikembangakan oleh komunitas tersebut. Dalam komunitas pecinta film Islami, ada saatnya dalam mencari perhatian dari para anggota lain, seorang anggota terpaksa mengikuti pola komunikasi mayoritas anggota didalam komunitas tersebut, sehingga pola komunikasi tersebut dapat dipahami semua orang atau bersifat universal. Jika pola komunikasi anggota tersebut memang merupakan karakter suatu kepribadian sendiri, tentu saja tetap memerlukan koreksi, misalnya dengan meminta tanggapan atau opini serta melakukan evaluasi dari orang lain yang ada di dalam komunitas.

Sehingga pola komunikasi yang dimiliki oleh setiap anggota komunitas dapat menciptakan pola komunikasi yang sinergis dan efektif serta mampu menyelesaikan permasalahan yang ada di dalam komunitas sehingga dapat mempererat hubungan diantara anggota-anggota komunitas Pecinta Film Islami yang ada di Bandung.

Apabila diaplikasikan secara benar komunikasi akan mencegah dan menghilangkan konflik antarpribadi, antarkelompok, antarsuku, antarbangsa, dan antarras. Hakikat komunikasi adalah proses penyampaian pesan dengan dengan menggunakan bahasa sebagai penyalurnya. Komunikasi berlangsung dalam berbagai tingkat kesengajaan untuk meraih tujuan dari komunikasi sendiri. Tujuan tersebut antara lain, mengubah sikap, opini, perilaku, dan mengubah masyarakat. Dimana dari tujuan tersebut dapat dilihat bahwa komunikasi tersebut memang berlangsung dari kesengajaan di mana fungsi dari komunikasi itu sendiri, menginformasikan, mendidik, menghibur, dan mempengaruhi (Marhaeni Fajar, 2009: 38).

Bateson dan Watzlawick mengemukakan bahwa hubungan merupakan bagian dari sebuah sistem. Orang-orang dalam suatu hubungan selalu menciptakan seperangkat pengharapan, memperkuat hubungan yang lama, atau mengubah pola interaksi yang sudah ada (Littlejohn, 1996: 251). 


\section{PENUTUP}

Komunitas Pecinta Film Islami merupakan komunitas yang memiliki anggota yang cukup banyak, salah satunya berada di regional kota bandung. Komunitas ini sering mengadakan kegiatan yang positif terutama dalam kegiatan yang berhubungan dengan dakwah islam, karena mengkaji film dari segi konten Islami yang disajikan film tersebut. Budaya Nobar dalam komunitas ini, membuat hubungan antar sesama anggota menjadi semakin baik dan erat, selain itu pula kajian terhadap film pun menjadi salah satu kegiatan yang menarik untuk menciptakan generasi yang memiliki kepedulian terhadap konten positif sebuah film, khususnya film yang ada di Indonesia. Nongkrong atau ngumpul-ngumpul di suatu lokasi seperti kafe juga menjadi hal penting untuk menjaga silaturahmi dari setiap anggota dari Kopfi yang berada di Bandung.

Anggotanya yang cukup banyak, kadang membuat keutuhan dan keharmonisan dari komunitas ini selalu di uji, sehingga perlu adanya pola komunikasi yang baik antar sesame anggota dari Komunitas Peconta Film Islami yang ada di Bandung ini.pola komunikasi tersebut yang nantinya akan mempersatukan opini dari setiap anggota, yang akhirnya menimbulkan keharmonisan dan kohesivitas didalam komunitas ini tetap terjaga. Proses evaluasi pun penting dalam komunitas ini, untuk mencari pergesekan opini yang nantinya akan menimbulkan konflik dan menyelesaikan konflik tersebut dengan baik dan efektif sehingga keutuhan anggota semakin terjaga. Konflik dan pergesekan mungkin terjadi tapi menjaga hubungan dan silaturahmi antar sesame anggota menjadi tujuan utama dalam komunitas ini, agar semakin utuh atau bahkan berkembangnya anggota, maka tujuan memajukan perfilman Indonesia, dan membuat film Indonesia memiliki konten Islami yang positif akan semakin tercapai.

\section{DAFTAR PUSTAKA}

Akarika et. All. (2017). Communication Flow Patterns and Institutional Harmony in Tertiary Institutions In Nigeria. International Journal of International Relations, Media and Mass Communication Studies, 3(6),1-37.

Effendy, O. U. (2003) Ilmu, teori dan filsafat komunikasi. Bandung : Citra Aditya Bakti.

Iskandar, J. (2017). Pengaruh Komunikasi Interpersonal dan Komunikasi Kelompok terhadap Kohesivitas Kelompok pada Supporter Persebaya Korwil Suramadu dalam Ultima Comm 9 (2), 90-109

Kaplan, H. B. dan Stiles, B.L. (2004) Adverse Social Comparison Processes and Negative Self-Feelings: A Test Of Alternative Models. Social Behavior and Personality, 2004. 
Aqoma Soleh

Littlejohn, S. W. (1992). Theories of Human Communication. (Edisi 2). New Mexcico: Wadsworth Publishing Company Albuquerque.

Littlejohn, S. W. (1996). Theories of Human Communication. Sixth Edition. USA: Wadsworth Publishing Company.

Marhaeni, F. (2009). Ilmu Komunikasi: Teori dan Praktik. Yogyakarta: Graha Ilmu.

Mulyana, D. (2008). Ilmu Komunikasi : Suatu Pengantar, Jakarta : PT. Remaja.

Silberstang, J. (2009). How Groups Learn:The Role of Communication Patterns, Cue Recognition, Context Facility, and Cultural Intelligence. SAGE Journal, 8(3), 327-349

Syahputra, O. A. (2012). Memahami Pola Komunikasi Kelompok Antar Anggota Komunitas Punk Semarang dalam The Messenger 4 (1), 43 - 62

Syamsuri. (2016) Pola Komunikasi Kelompok Komunitas Muballig kota Makasar. Ilmu Dakwah: Academic Journal for Homiletic Studies 10 (2), 78-99

Yardha, S. (2017). Komunikasi kelompok Dalam Membentuk Konsep Diri pada Komunitas Seribu Guru Aceh di Banda Aceh dalam Jurnal Ilmiah Liski 3 (2), 81-92 